\title{
Radium balance in discharge waters from coal mines in Poland the ecological impact of underground water treatment
}

\author{
S. Chałupnik and M. Wysocka \\ Laboratory of Radiometry, Central Mining Institute 40-166 Katowice, \\ Pl. Gwarkow 1, Poland \\ e-mail: s.chalupnik.@gig.katowice.pl
}

\begin{abstract}
Saline waters from underground coal mines in Poland often contain natural radioactive isotopes, mainly ${ }^{226} \mathrm{Ra}$ from the uranium decay series and ${ }^{228} \mathrm{Ra}$ from the thorium series. More than $70 \%$ of the total amount of radium remains underground as radioactive deposits due to spontaneous co-precipitation or water treatment technologies, but several tens of $\mathrm{MBq}$ of ${ }^{226} \mathrm{Ra}$ and even higher activity of ${ }^{228} \mathrm{Ra}$ are released daily into the rivers along with the other mine effluents from all Polish coal mines. Mine waters can have a severe impact on the natural environment, mainly due to its salinity. Additionally high levels of radium concentration in river waters, bottom sediments and vegetation were also observed. Sometimes radium concentrations in rivers exceeded $0.7 \mathrm{kBq} / \mathrm{m}^{3}$, which was the permitted level for waste waters under Polish law. The investigations described here were carried out for all coal mines and on this basis the total radium balance in effluents has been calculated. Measurements in the vicinity of mine settling ponds and in rivers have given us an opportunity to study radium behaviour in river waters and to assess the degree of contamination. For removal of radium from saline waters a method of purification has been developed and implemented in full technical scale in two of Polish coal mines. The purification station in Piast Colliery was unique, the first underground installation for the removal of radium isotopes from saline waters. Very good results have been achieved - approximately $6 \mathrm{~m}^{3} / \mathrm{min}$ of radium-bearing waters were treated there, more than $100 \mathrm{MBq}$ of ${ }^{226} \mathrm{Ra}$ and ${ }^{228} \mathrm{Ra}$ remained underground each day. Purification has been started in 1999, therefore a lot of experiences have been gathered during this period. Since year 2006, a new purification station is working in another colliery, Ziemowit, at the level -650 meters. Barium chloride is used as a cleaning agent, and amount of water to be purified is reaching $9 \mathrm{~m}^{3} / \mathrm{min}$. Technical measures such as inducing the precipitation of radium in gobs, decreasing the amount of meteoric inflow water into underground workings etc., have been undertaken in several coal mines, and as a result of these measures the total amount of radium released to the surface waters is much has diminished significantly during the last 15 years.
\end{abstract}

\section{INTRODUCTION}

Very often human activity, connected with the exploitation of mineral resources, leads to the contamination of the natural environment. Sometimes natural radionuclides are released or concentrated as waste material. In Poland the main source of waste and by-products with enhanced concentration of natural radionuclides is power industry, based on the coal exploitation and combustion. In hard coal mining industry 50 million tons of different waste materials are produced annually. As a result of coal combustion in power plants, the area of fly ash and sludge piles is increased by several $\mathrm{km}^{2}$ per year [Michalik et al., 1995].

Upper Silesian Coal Basin (USCB) is located in the Southern-West part of Poland. Presently there are 35 underground coal mines there extracting approximately $100 \mathrm{mln}$ tons of coal per year. The depth of mine workings is from 350 to $1050 \mathrm{~m}$. Upper Silesia is characterized by a very complicated and differentiated geological structure with numerous faults and other tectonic dislocations. Additionally, the area is very affected by mining.

Two hydrological regions of the Coal Basin have been distinguished. First region is located in southern and western Silesia with thick strata of sediments covering carboniferous formation. This overlay is built mainly by Miocene clays and silts. The thickness of this rocks is up to $700 \mathrm{~m}$. Such 
strata make almost impossible migration of water an gases. In the second region Miocene clays do not occur. Carboniferous strata are covered by and Quaternary sediments, slightly compacted. The oldest formations of this area form isolated sediments of Permian or Triassic limestone strongly fissured. There are numerous outcrops of coal seams. These formations enable very easy migration of water and gases.

An additional and unexpected component of the radioactive contamination of the natural environment, and different from that usually associated with this kind of industry, is caused by underground coal exploitation. In many of coal mines, located in Upper Silesian Coal Basin waters with enhanced radium content occur [Lebecka et al., 1986]. Sometimes in radium-bearing brines barium ions are also present, in concentrations up to $2 \mathrm{~g} / \mathrm{l}$. Such waters were classified as radium-bearing type A waters. On the other hand, in the second kind of waters, which have been called type B, no barium can be found but radium and sulphate ions are present.

In the area of Upper Silesian Coal Basin (USCB) operate of about 35 underground coal mines. The total water outflow from these mines is about $750000 \mathrm{~m}^{3} /$ day. The salinity of these brines is far higher than that of ocean water. The total amount of salt (total dissolved solids - TDS) carried with mine waters to the rivers is about 10000 tonnes/day. The commonest ions in these brines are $\mathrm{Cl}^{-}$and $\mathrm{Na}^{+}$with concentrations up to $70 \mathrm{~g} / \mathrm{l}$ and $40 \mathrm{~g} / \mathrm{l}$ respectively, additionally brines usually contain several grams per litre of $\mathrm{Ca}^{2+}$ and $\mathrm{Mg}^{2+}$ and significant amounts of other ions [Tomza \& Lebecka, 1981]. Waters with high radium concentration occur mainly in the southern and central part of the coal basin, where coal seams are overlaid by a thick layer of impermeable clays [Rozkowski \& Wilk, 1992]. These saline waters cause severe damage to the natural environment, owing mainly to their high salinity (sometimes $>200 \mathrm{~g} / \mathrm{l}$ ), but also their high radium concentration, reaching $390 \mathrm{kBq} / \mathrm{m}^{3}$ [Skubacz et al., 1990].

The presence of barium in waters is the most important factor for the further behaviour of radium isotopes in mine galleries or on the surface. From type A waters radium and barium always co-precipitate as sulphates, when such waters are mixed with any water containing sulphate ions. As a result of the precipitation, barium sulphate deposits with highly enhanced radium concentrations are formed [Lebecka et al., 1986, Michalik et al., 1999]. The total activity of radium isotopes in these sediments may sometimes reach $400 \mathrm{kBq} / \mathrm{kg}$. In comparison, average radium content in soil is $25 \mathrm{~Bq} / \mathrm{kg}$ [UNSCEAR, 1982]. In case of radium-bearing type B waters, no precipitation occurs due to the lack of the barium carrier, and that is why the increase of radium content in sediments is much lower that ones originated from type A waters.

\section{APPLIED METHODS AND INSTRUMENTATION}

Radioactivity of waters from coal mines is mostly from radium isotopes $-{ }^{226} \mathrm{Ra}$ from the uranium series and ${ }^{228} \mathrm{Ra}$ from the thorium. A method of chemical separation of radium, developed by Goldin [Goldin, 1961], has been modified for liquid scintillation counting [Chalupnik \& Lebecka, 1990; Chalupnik \& Lebecka, 1993]. Radium is co-precipitated with barium in form of sulphates and this precipitate is mixed with liquid gelling scintillator. The prepared samples were measured by a low background liquid scintillation spectrometer (QUANTULUS, PerkinElmer). This counter is equipped in alpha/beta separation and anti-coincidence shield, which enables measurements of ${ }^{226} \mathrm{Ra}$ concentration above $3 \mathrm{~Bq} / \mathrm{m}^{3}$ with simultaneous measurements of ${ }^{228} \mathrm{Ra}\left(\mathrm{LLD}=30 \mathrm{~Bq} / \mathrm{m}^{3}\right)$ and ${ }^{224} \mathrm{Ra}\left(\mathrm{LLD}=50 \mathrm{~Bq} / \mathrm{m}^{3}\right)$. In addition, the procedure enables the simultaneous preparation of ${ }^{210} \mathrm{~Pb}$, which can separated from radium isotopes at the last stage of analysis and also measured in the LS spectrometer with a detection limit of $20 \mathrm{~Bq} / \mathrm{m}^{3}$.

\section{SYSTEM OF MONITORING IN THE VICINITY OF COAL MINES}

In the mining industry in Poland, monitoring of the radioactivity of mine waters, precipitates as well as gamma doses was obligatory since 1989 till 2003. 
Monitoring of radioactive contamination caused by effluents and tailings from coal mines must be done since 1986 [Guidelines, 1986]. Due to these regulations the following measurements must be done in mine's vicinity:

I. The concentration of ${ }^{226} \mathrm{Ra}$ and ${ }^{228} \mathrm{Ra}$ in effluent from the settlement pond, in river above and below the discharge point, in water supplies nearby discharge point.

II. The concentrations of natural radionuclides in solid samples, dumped onto the piles.

Such complex monitoring system gives an opportunity to obtain a complete picture of the influence of a certain mine on the underground and surface employees as well as on inhabitants of adjoining areas.

Concentration of radium isotopes in original water samples from different coal mines varies in a very wide range - from 0 to $110 \mathrm{kBq} / \mathrm{m}^{3}$ for ${ }^{226} \mathrm{Ra}$ and from 0 to $70 \mathrm{kBq} / \mathrm{m}^{3}$ for ${ }^{228} \mathrm{Ra}$ [Report, 2004]. In 80's waters with radium concentration above $1.0 \mathrm{kBq} / \mathrm{m}^{3}$ were found in 43 out of 65 coal mines in Upper Silesian Coal Basin. The highest concentrations of radium were measured in highly mineralised waters from deeper levels in radium-bearing waters type A. The ratio of ${ }^{226} \mathrm{Ra}$ to ${ }^{228} \mathrm{Ra}$ in radium-bearing waters type $\mathrm{A}$ was in average of about 2:1. Contrary in radium-bearing waters type $\mathrm{B}$ there were more ${ }^{228} \mathrm{Ra}$ than ${ }^{226} \mathrm{Ra}$, the ratio ${ }^{226} \mathrm{Ra}:{ }^{228} \mathrm{Ra}$ was from $1: 2$ up to $1: 3$. Concentration of ${ }^{226} \mathrm{Ra}$ in these waters reached $20 \mathrm{kBq} / \mathrm{m}^{3}$, while maximum concentration of ${ }^{228} \mathrm{Ra}$ was as high as $32 \mathrm{kBq} / \mathrm{m}^{3}$. These values justify the statement that Upper Silesian radium-bearing waters belong to the waters with highest known radium concentration.

Original waters flowing into mine workings from the rocks from different aquifers are collected in gutters in underground galleries, brought together from different parts of the mine, clarified and pumped out to the surface. Radium concentration in these mixed waters was lower than in original water and did not exceed $25 \mathrm{kBq} / \mathrm{m}^{3}$ of ${ }^{226} \mathrm{Ra}$ and $14 \mathrm{kBq} / \mathrm{m}^{3}$ of ${ }^{228} \mathrm{Ra}$ [Report, 2004].

Basing on the results of measurements of radium concentration in the original waters inflows into the mine workings and on data on the flow rates of water provided by the mine hydrologists, the total activities of both radioisotopes of radium flowing with water to different parts of mines and to different mines were calculated. This results were compared with values obtained using radium concentrations in mixed waters taken from the drainage system (from gutters) from different parts of mines and corresponding flow rates obtained from the mines. The difference is indicating the activity of radium remaining in underground mine workings due to spontaneous precipitation of radium and barium sulphates or due to applied purification of water. The calculated activity of radium remaining in underground mine workings as deposits in all Upper Silesian coal mines is $580 \mathrm{MBq} /$ day of ${ }^{226} \mathrm{Ra}$ and $530 \mathrm{MBq} /$ day of ${ }^{228} \mathrm{Ra}$. These values can not be considered as very accurate, since the uncertainty of measurements of flow rates of small inflows is rather large. The approximate amount of ${ }^{226} \mathrm{Ra}$ in water inflows in coal mines in USCB have been calculated as high as $650 \mathrm{MBq} /$ day (i.e. $230 \mathrm{GBq}$ per year) while for ${ }^{228} \mathrm{Ra}$ this value is of about $700 \mathrm{MBq} /$ day or $255 \mathrm{GBq}$ per year. Although radium concentrations in waters type B were usually lower than in waters type A the total inflows to mines where radium-bearing waters type $\mathrm{B}$ occur were much higher. As a result the total activity of radium carried with water type B was higher. The highest values for a single mine (with waters type B) were: $78 \mathrm{MBq}$ per day of ${ }^{226} \mathrm{Ra}$ and $145 \mathrm{MBq}$ per day of ${ }^{228} \mathrm{Ra}$.

In comparison corresponding values of inflows of radium with saline waters in 4 copper mines in Poland were: $31 \mathrm{MBq}$ of ${ }^{226} \mathrm{Ra}$ and $3 \mathrm{MBq}$ of ${ }^{228} \mathrm{Ra}$ per day.

\section{ASSESSMENT OF RADIUM BALANCE IN DISCHARGE WATERS}

One of the biggest advantages of the monitoring system in Upper Silesia region is a possibility to make an assessment of radium balance in discharge waters periodically. For instance in years 1987, 1995, 2003 and 2006 such assessments have been prepared. For the calculations of about 300 results of mine waters have been taken as well as 40 analyses of river waters have been done. The term "mine waters" means not only mine waters but also river waters close to the discharge points. Term "river waters" is used for the samples taken at the sampling points of regional monitoring system of water quality. All 
the data are included in the mine waters database in the Laboratory of Radiometry as the element of the radiation hazard monitoring and environmental monitoring. A comparison of assessment results in chosen periods is shown in Table 1.

The assessment of the total activity of radium released from coal mines in Upper Silesia with waste water is based on:

- results of determination of radium isotopes in waters released by collieries;

- data on amount of water released by individual mines.

We have also made an estimation of total activity of radium which remains in underground workings in a form of deposit precipitated out of radium-bearing waters either due to unintended mixing of natural waters of different chemical composition or due to the purification of radium-bearing waters. This estimation has been done basing on:

- results of determination of radium isotopes in original waters inflowing to the underground mine workings from the rocks;

- rough estimation of the amounts of water inflows from different sources or parts of mines;

- calculated value of the total activity of radium pumped out from underground mine workings with waste waters by individual mines.

Table 1. Comparison of radium balance assessment in rivers from Upper Silesia region.

\begin{tabular}{|c|c|c|c|c|c|c|}
\hline \multirow[t]{2}{*}{ Catchment area } & \multicolumn{2}{|c|}{$\begin{array}{c}\text { Total activity } \\
\mathbf{1 9 9 5} \\
{[\mathrm{MBq} / \text { day }]}\end{array}$} & \multicolumn{2}{|c|}{$\begin{array}{c}\text { Total activity } \\
\mathbf{2 0 0 3} \\
\text { [MBq/day] } \\
\end{array}$} & \multicolumn{2}{|c|}{$\begin{array}{c}\text { Total activity } \\
\mathbf{2 0 0 6} \\
{[\mathrm{MBq} / \mathrm{day}]} \\
\end{array}$} \\
\hline & ${ }^{226} \mathrm{Ra}$ & ${ }^{228} \mathrm{Ra}$ & ${ }^{226} \mathrm{Ra}$ & ${ }^{228} \mathrm{Ra}$ & ${ }^{226} \mathrm{Ra}$ & ${ }^{228} \mathrm{Ra}$ \\
\hline $\begin{array}{l}\text { Inflows into "OLZA" } \\
\text { pipeline from } 11 \text { mines }\end{array}$ & 9.8 & 6.7 & 6.8 & 6.8 & 6.5 & 6.5 \\
\hline $\begin{array}{l}\text { Olza River - discharge of } \\
\text { "Olza" pipeline }\end{array}$ & 1.6 & 1.4 & 2.5 & 1.8 & 2.3 & 1.6 \\
\hline $\begin{array}{l}\text { Ruda-Nacyna Rivers(3 } \\
\text { mines) }\end{array}$ & 2.2 & 1.4 & 0.7 & 0.7 & 1.2 & 1.1 \\
\hline $\begin{array}{l}\text { Bierawka } \\
\text { River (5 mines) }\end{array}$ & 1.6 & 1.2 & 2.7 & 3.2 & 1.8 & 1.4 \\
\hline $\begin{array}{l}\text { Bytomka } \\
\text { River ( } 5 \text { mines) }\end{array}$ & 0.4 & 0.5 & 1.5 & 3.0 & 1.2 & 1.9 \\
\hline $\begin{array}{l}\text { Klodnica } \\
\text { River (7 mines) }\end{array}$ & 2.6 & 2.9 & 2.6 & 3.7 & 2.8 & 2.9 \\
\hline Rawa River (4 mines) & 0.2 & 0.2 & 1.2 & 2.7 & 0.6 & 2.1 \\
\hline $\begin{array}{l}\text { Black Przemsza } \\
\text { River (4 mines) }\end{array}$ & 1.6 & 3.1 & 1.3 & 2.3 & 1.5 & 2.8 \\
\hline Gostynka River (3 mines) & 133.9 & 248.1 & 61.1 & 147.6 & 52.4 & 128.5 \\
\hline Mleczna River (2 mines) & 1.3 & 2.4 & 1.5 & 3.3 & 1.5 & 3.3 \\
\hline $\begin{array}{l}\text { Brynica } \\
\text { River (4 mines) }\end{array}$ & 0.7 & 0.7 & 1.4 & 2.4 & 1.2 & 1.8 \\
\hline $\begin{array}{l}\text { Przemsza } \\
\text { River (2 mines) }\end{array}$ & 0.4 & 0.4 & 2.3 & 5.6 & 1.2 & 2.4 \\
\hline $\begin{array}{l}\text { Bobrek } \\
\text { River ( } 3 \text { mines) }\end{array}$ & 0.2 & 0.2 & 0.3 & 1.2 & 0.8 & 1.5 \\
\hline $\begin{array}{l}\text { Upper Vistuala } \\
\text { (4 mines) }\end{array}$ & 73.0 & 117.2 & 42.9 & 84.2 & 8.9 & 19.8 \\
\hline $\begin{array}{l}\text { Total: } 35 \text { active } \\
\text { mines } 30 \text { abandoned }\end{array}$ & 219.1 & 380.1 & 120.1 & 258.2 & 77.4 & 169.5 \\
\hline
\end{tabular}

Much more accurate were the results of calculations of the total activities of radium present in water pumped out from individual mines. These values were calculated basing on the radium concentration determined in these waters and on data of amount of water provided by mines (see fig. 1. and table 1). 


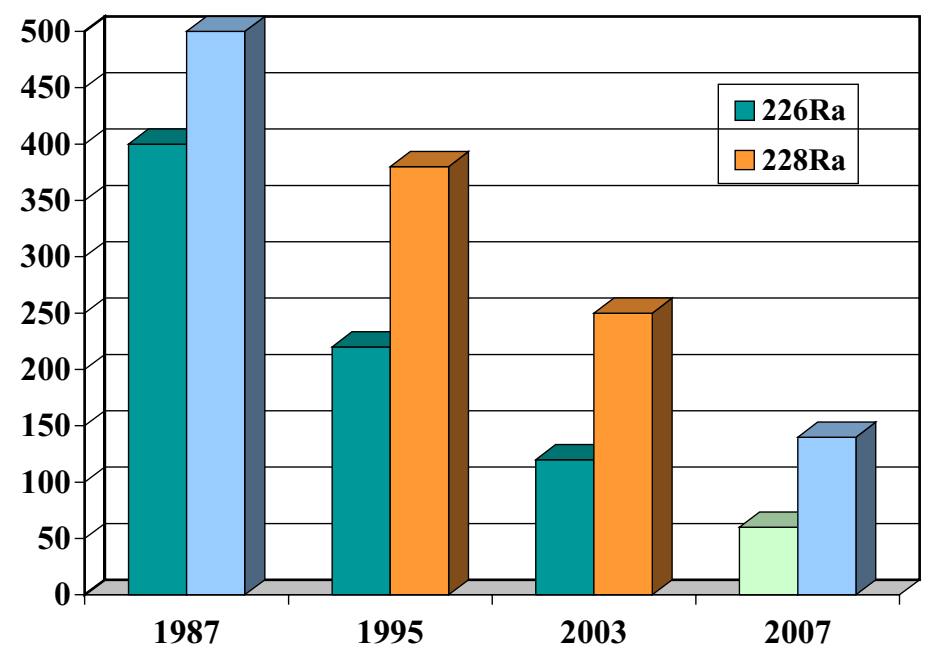

Figure 1. Changes of radium activity, released daily with waters from all coal mines in Poland [MBq/day].

Samples of discharged waters were taken from settling ponds. In outflows from these ponds in $87 \%$ mines ${ }^{226} \mathrm{Ra}$ concentration exceeds $0.008 \mathrm{kBq} / \mathrm{m}^{3}$, in $25 \%{ }^{226} \mathrm{Ra}$ concentration is higher than $0.1 \mathrm{kBq} / \mathrm{m}^{3}$ and in $8 \%$ exceeded permissible level - i.e. $0.7 \mathrm{kBq} / \mathrm{m}^{3}$ [Decree, 1989].

In rivers enhanced concentrations of radium can be observed many kilometres down from the discharge points. This is mainly true for radium-bearing waters type $\mathrm{B}$, because out of these waters radium is not easily precipitated. The highest value of ${ }^{226} \mathrm{Ra}$ concentration was as high as $1.3 \mathrm{kBq} / \mathrm{m}^{3}-$ it was found in a small stream near it's conjunction with Vistula river.

The significant decrease of daily discharge of radium was observed in the period 1987-1995. Very first assessment of radium ${ }^{226} \mathrm{Ra}$ in mine effluents has been done in 1987 , giving the value of the daily release at level $400 \mathrm{MBq}$. At that time no results of ${ }^{228} \mathrm{Ra}$ measurements were available. Results of another assessment, prepared in 1995 showed a significant decrease of radium activity in mine waters, released into natural environment, roughly by factor 2. There were two reason of this effect. Firstly, the purification of A type mine waters has been started in several coal mines in catchment areas of Olza river and Upper Vistula. The another reason was due to economical changes in the mining industry - dewatering of deep mines was more and more expensive and hydro-technical solutions have been applied in numerous mines to reduce water inflows into underground galleries, with special emphasis on brines.

In the last period the decrease of radium activity in discharge waters is mainly due to the purification of B type brines in Piast Colliery (started in 1999) and construction of another treatment station in the year 2006 in Ziemowit Mine. In Piast Mine the implementation of the treatment technology on deeper of the horizons in the mine caused the decrease of radium release from the mine at level $150 \mathrm{MBq} /$ day$60 \mathrm{MBq} /$ day of ${ }^{226} \mathrm{Ra}$ and $90 \mathrm{MBq} /$ day of ${ }^{228} \mathrm{Ra}$. The application of the purification technology in another mine should further reduce radium discharge. Additionally, purification system for second horizon of Piast mine is under designing, and it will solve most of the problems with radium contamination of river waters in Upper Silesia region.

In 90's enhanced radium concentrations were mainly observed in the Vistula river, into which most of the radium is discharged with B type waters - approximately $200 \mathrm{MBq}$ of ${ }^{226} \mathrm{Ra}$ and $350 \mathrm{MBq}$ of ${ }^{228} \mathrm{Ra}$ per day. Concentration of ${ }^{226} \mathrm{Ra}\left(0.035 \mathrm{kBq} / \mathrm{m}^{3}\right)$ was observed in Vistula in Cracow $-70 \mathrm{~km}$ downstream from Upper Silesia. Some of these waters were not discharged directly to Vistula river, but to it's tributaries. The influences of singular inflows were very clearly. Moreover, waters from first 
mine were A type and the difference of radium behaviour (fast precipitation) in comparison with other 3 mines (waters B type) was very evident. Different situation was observed in the vicinity of Oder river, where in coal mines occur mainly waters type $\mathrm{A}$. The amount of radium discharged into this river was much lower - $20 \mathrm{MBq}$ per day of ${ }^{226} \mathrm{Ra}$ and $25 \mathrm{MBg} /$ day of ${ }^{228} \mathrm{Ra}$. As a result concentrations of radium in Oder were below $0.01 \mathrm{kBq} / \mathrm{m}^{3}$.

At the beginning of new century a treatment of mine waters (type B - without barium) has been started in underground galleries of Piast mine (1999). The total activity of radium isotopes in discharge waters decreased significantly, but still concentrations of radium isotopes in some rivers in Upper Silesia were clearly enhanced as compared with natural levels. In comparison with data from other locations, concentrations of radium isotopes in rivers in USCB are significantly higher. Enhanced concentrations of radium in river waters in Upper Silesia are caused solely by the influence of mine waters.

One of the collieries, releasing radium isotopes into surface settling pond and finally into Vistula River was Ziemowit Mine. In this mine saline brines are very common, and the total inflow into mine galleries exceeds $20 \mathrm{~m}^{3} / \mathrm{min}$. Radium concentration in these brines is as high as $12 \mathrm{kBq} / \mathrm{m}^{3}$ for ${ }^{226} \mathrm{Ra}$ and $20 \mathrm{kBq} / \mathrm{m}^{3}$ for ${ }^{228} \mathrm{Ra}$. Due to the lack of barium in brines (type B waters) from Ziemowit Mine the spontaneous coprecipitation of radium was negligible and only small part of radium remained underground as a result of adsorption on bottom sediments in underground water galleries. Therefore Ziemowit Colliery was the main source of the contamination of small brook, called Potok Golawiecki, a tributary of Vistula River and Vistula itself. In 2003 almost $50 \%$ of total activity released from all mines in USCB was dumped into surface waters from Ziemowit. Of about $60 \mathrm{MBq}$ of ${ }^{226} \mathrm{Ra}$ and $100 \mathrm{MBq}$ of ${ }^{228} \mathrm{Ra}$ was released daily, despite the fact, that concentrations of radium isotopes in effluents from Ziemowit Mine weren't very high, reaching $1.3 \mathrm{kBq} / \mathrm{m}^{3}$ in case of ${ }^{226} \mathrm{Ra}$ and for ${ }^{228} \mathrm{Ra}-2.5 \mathrm{kBq} / \mathrm{m}^{3}$.

The ecological effect of the purification is the most important issue. At the outflow from the purification system, at the level $-650 \mathrm{~m}$ the removal efficiency is above $95 \%$. On the surface the efficiency is lower, due to mixing with untreated waters from level $-500 \mathrm{~m}$, But at the inflow of saline waters into the settling pond, as well as at the outflow from that pond, concentrations of radium isotopes are approximately $80-85 \%$ lower than before purification. It corresponds to the decrease of about $40 \mathrm{MBq}$ for ${ }^{226} \mathrm{Ra}$ and $60 \mathrm{MBq}$ for isotope ${ }^{228} \mathrm{Ra}$ of daily release from the Ziemowit Mine. It means, that the total amount of radium, discharged into the Potok Golawiecki and Vistula rivers is much lower, by a value $100 \mathrm{MBq} /$ day. This station in still in preliminary period of activity and more detailed reports will be published later.

Due to release of radium-bearing mine waters from coal mines there is a contamination of river waters. As a result radium concentration in some small rivers exceeds permissible level for radioactive wastes. Therefore development and application of purification methods is justified and further efforts should be done to reduce the contamination of rivers, particularly of Vistula River and it's tributaries.

On the other hand we must take into account, the exploitation of deeper coal seams will cause more problems with inflows of radium-bearing brines into underground workings, even in these mines where no radium problems exist right now. Therefore periodical monitoring of discharge waters is necessary. Another legal problem must be also solved - responsibility for monitoring of waters, released from abandoned mines

\section{SUMMARY}

- Coal mining may cause significant pollution of the natural environment due to release of waste waters with enhanced concentrations of natural radionuclides (mainly radium isotopes. This phenomenon is well known not only in Upper Silesian Coal Basin but also in other regions of underground exploitation of coal (Ruhr Basin), oil and gas or other resources.

- Due to mitigation measures, undertaken by mines, the significant improvement can be observed during last two decades. In most cases radium concentrations in discharge waters are low and surface 
waters are not contaminated. Moreover, further decrease of radium release is predicted as a result of underground mine water purification in two collieries.

- Monitoring system of natural radionuclides in waste waters and river waters is an important element of the prevention against the pollution of the natural environment. Moreover, it is a source of data for optimization of ground reclamation of previously contaminated areas (mainly settling ponds) of abandoned coal mines.

Of course, further improvement of the system is required as well as solution of important legal problems, related with liquidation of coal mines, harmonization with EU regulations etc.

\section{References}

[1] Zgadzaj J., Skubacz K. and Chałupnik S., The influence of radon and it's progeny emitted from the exhaust shafts of coal mines on the contamination of the outdoor air. International Conference "Technologically enhanced natural radiation caused by non-uranium mining”, Katowice, Główny Instytut Górnictwa 1996.

[2] Lebecka J., i inni, Monitoring of Radiation Exposure from Different Natural Sources in Polish Coal Mines. International Conference on Occupational Safety in Mining, Vol. 2, Toronto, Canadian Nuclear Association 1985.

[3] Skubacz K., Lebecka J., Chałupnik S. and Wysocka M., Possible changes in radiation background of the natural environment caused by coal mines activity. International Symposium on Nuclear Techniques in Exploration and Exploitation of Energy and Mineral Resources, IAEA-SM-308, Vienna, IAEA 1990.

[4] Koster H.W., Marwitz P.A., Berger G.W., van Weers A.W. and Hagel P., ${ }^{210} \mathrm{Po},{ }^{210} \mathrm{~Pb},{ }^{226} \mathrm{Ra}$ in Aquatic Ecosystems and Polders, Anthropogenic Sources, Distribution and Enhanced Radiation Doses in the Netherlands. The Natural Radiation Environment, Nuclear Technology Publishing, Vol. 45, No. 1-4, 1992.

[5] Khademi A., Alemi A. and Nasseri A., Transfer of radium of soil to plants in an area of high natural radioactivity in Ramsar, Iran. Conference on Natural Radiation Environment III, US DOE Report CONF-780422, Bethseda, Maryland, 1980.

[6] Rajaretnam G. and Spitz, H.B., Effect of Leachability on Environmental Risk Assessment for Naturally Occurring Radioactivity Materials in Petroleum Oil Fields. Health Physics, Vol. 78 (2), 2000.

[7] Peic T., i inni, Formation waters from oil and natural gas production: potential polluting source by Radium-226. International Symposium on the Natural Radiation Environment (NRE-VI), w: Environment International, Vol. 22, supl. 1, Pergamon Press 1996.

[8] Gucało L.K., Characteristics of radium distribution in underground waters of DnieprowskoDonieckoj Basin. Gieochimja, vol. 12, 1964.

[9] Dickson B.L., Evaluation of the Radioactive Anomalies Using Radium Isotopes in Groundwaters. Journal of Geochemical Exploration, Vol. 19, 1966.

[10] Gans I., i inni, Radium in waste water from coal mines and other sources in FRG. Second Symposium on Natural Radiation Environment, Bombay, India, Bethseda, DOE Symposium Series 1981.

[11] Paschoa A.S. and Nobrega A.W., Non-nuclear mining with radiological implications in Araxa. International Conference On Radiation Hazards in Mining, Golden, Colorado, American Institute of Mining, Metallurgical, and Petroleum Engineers Inc., 1981.

[12] Rogoż M. and Posyłek E., Górnicze i geologiczne metody ograniczania zrzutów słonych wód $z$ kopalń wegla kamiennego (Geological and technical methods of brines release limitation from coal mines). "Kierunki zagospodarowania zasolonych wód z kopalń węgla kamiennego", Główny Instytut Górnictwa, Katowice 1991 (in Polish). 
[13] Lebecka J., i inni, Influence of Mining Activity on Distribution of Radium in the Natural Environment. 4th Working Meeting Isotopes in Nature, Leipzig, Academy of Sciences of the GDR 1987.

[14] Lebecka J., Skubacz K., Chałupnik S. and Wysocka M., Skażenia promieniotwórcze środowiska naturalnego na Górnym Ślaku powodowane przez wody kopalniane i promieniotwórcze osady (Radioactive pollution of the natural environment in Upper Silesia, caused by mine waters and sediments).- Wiadomości Górnicze, no. 6, Katowice 1991 (in Polish).

[15] Lebecka J., Chałupnik S. and Wysocka M., Radioactivity of Mine Waters in Upper Silesian Coal Basin, and its Influence on Natural Environment. $5^{\text {th }}$ International Mine Water Congress, Nottingham, International Mine Water Association 1994.

[16] Lebecka J., Chałupnik S. and Śliwka M., Wyniki badań zachowania sie radu podczas transportu słonych wód rurociagami (na przykładzie kolektora wód słonych OLZA). (Results of investigations of radium behaviour in pipelines on example of OLZA pipeline) Wiadomości Górnicze 5/92, Katowice 1992 (in Polish).

[17] Tomza I. and Lebecka J., Radium-bearing waters in coal mines: occurrence, methods of measurements and radiation hazard. International Conference On Radiation Hazards in Mining, Golden, Colorado, American Institute of Mining, Metallurgical, and Petroleum Engineers Inc., 1981.

[18] Ministerstwo Górnictwa i Energetyki, Wytyczne kontroli skażeń promieniotwórczych środowiska naturalnego powodowanych przez kopalnie wegla kamiennego (Guidelines for the monitoring of radioactive contamination of the natural environment, caused by coal mines - Ministry of Mining and Energy). MGiE Katowice 1986 (in Polish).

[19] Chałupnik S. and Wysocka M., Removal of radium from mine waters - the experience from the coal mine. $7^{\text {th }}$ International Mine Water Association Congress, 2000, ed. Silesian University. 